\section{Analisis Pelayanan Jasa Pengiriman Barang Pada PT Tiki Jalur Nugraha Ekakurir (JNE) Pontianak}

Dr. Simon Ahie, S.E., M.M.

Sekolah Tinggi Ilmu Ekonomi “Indonesia” Pontianak
Pelayanan Jasa aspek tangibles

\begin{abstract}
Tidak terlepas dari tugas dan fungsi perusahaan jasa pengiriman barang yaitu menjaga dan mengantarkan kiriman barang pelanggan dengan keadaan baik sampai pada tujuannya. Oleh karena itu, penting untuk mengetahui persepsi konsumen pengguna jasa pengiriman barang PT Tiki Jalur Nugraha Ekakurir (JNE) Pontianak terhadap pelayanan yang diberikan, untuk mengetahui faktor penghambat kurangnya pelayanan terhadap konsumen pengguna pelayanan jasa pengiriman barang PT Tiki Jalur Nugraha Ekakurir (JNE) Pontianak serta untuk mengetahui kebijakan-kebijakan yang diambil oleh pihak pimpinan PT Tiki Jalur Nugraha Ekakurir (JNE) dalam meningkatkan jumlah pelanggan.Untuk memberikan pelayanan kepada pelanggan harus diperhatikan aspek tangibles (bukti fisik), reliability (keandalan), responsiveness (ketanggapan), assurance (jaminan dan kepastian), serta empathy (perhatian). Kesimpulan yang dapat diambil peneliti adalah kebijakan yang diambil oleh PT Tiki Jalur Nugraha Ekakurir (JNE) Jl. H.O.S. Cokroaminoto No. 100 Pontianak dengan memperhatikan kualitas pelayanan. Pelayanan yang maksimal dan perhatian yang diberikan kepada pelanggan, akan memberikan tingkat kepuasan pelanggan atas pelayanan yang diberikan oleh PT Tiki Jalur Nugraha Ekakurir (JNE) Jl. H.O.S. Cokroaminoto No. 100 Pontianak yang hingga saat ini dikatakan cukup baik.
\end{abstract}

Keywords: Pelayanan Jasa aspek tangibles (bukti fisik), reliability (keandalan), responsiveness (ketanggapan), assurance (jaminan dan kepastian), serta empathy (perhatian) 


\section{PENDAHULUAN}

Globalisasi telah menyebabkan persaingan semakin ketat, tak terkecuali

Pelayanan Jasa aspek tangibles

002 dengan dengan industri jasa kurir. Hal ini menyebabkan perusahaan-perusahaan dalam industri ini berusaha untuk saling memperhatikan kebutuhan dan keinginan para pelanggannya, serta berusaha untuk memberikan nilai yang paling tinggi kepada para pelanggannya dibandingkan para pesaingnya.

Pemberian nilai yang paling tinggi kepada para pelanggan ini dapat dilakukan dengan memberikan harga yang relatif murah disertai dengan pelayanan yang menyenangkan. Tujuan dari pemberian nilai yang tinggi kepada pelanggan ini adalah untuk menarik minat konsumen agar membeli produk yang dihasilkan oleh perusahaan, termasuk para konsumen yang membutuhkan jasa kurir. Kepuasan pelanggan ini dapat tercapai apabila perusahaan jasa kurir tersebut mampu memberikan layanan yang optimal sesuai dengan keinginan para pengguna jasa tersebut.

Adapun potensi dari industri jasa kurir terbilang bagus. Saat ini, kebutuhan konsumen terhadap jasa kurir semakin meningkat, terutama kebutuhan dari industri. Hal ini dapat dilihat pada tren bisnis saat ini dimana perusahaan lebih memfokuskan kegiatan usahanya pada core business-nya, sehingga perusahaan tidak ingin direpotkan dengan hal-hal yang bukan menjadi kegiatan inti perusahaan. Sedangkan potensi dari sisi konsumen perseorangan, saat ini mereka juga semakin membutuhkan jasa kurir untuk memenuhi kebutuhannya akan pengiriman barang, termasuk dokumen-dokumen. PT Tiki Jalur Nugraha Ekakurir (JNE) merupakan salah satu perusahaan dalam negeri yang bergerak dalam industri ini.

Pelayan lain yang memperngaruhi kepuasan pelanggan ini antara lain penitipan, sortir, pengangkutan dan penyerahan barang yang akan menentukan ketepatan waktu penyampaian, keutuhan, dan kualitas penyampaian barang kiriman. Keempat kegiatan tersebut yaitu, penitipan, sortir, pengangkutan, dan penyerahan barang kiriman yang merupakan titik kualitas layanan dari jasa kurir, akan membentuk kualitas layanan PT TIKI JNE Cabang Pontianak.

Salah satu prasyarat untuk memberikan kualitas layanan yang tinggi adalah penetapan standar pelayanan berdasarkan persepsi manajemen, dalam hal ini manajemen PT TIKI JNE Cabang Pontianak terhadap ekspektasi pelanggan. Oleh karena itu, manajemen perusahaan juga harus memahami keinginan para 
pelanggannya dan menterjemahkannya ke dalam program-program yang tercemin dalam proses penyampaian jasa pengiriman barang.

Ada beberapa hal penting dalam mengukur tingkat kepuasan pelanggan PT Jasa aspek tangibles

TIKI JNE Cabang Pontianak, diantaranya adalah mengetahui harapan atau keinginan pelanggan atas jasa yang diberikan dan mengetahui persepsi pelanggan atas jasa yang telah diberikan oleh perusahaan. Tentunya harapan dan keinginan pelanggan juga 003 dipengaruhi oleh beberapa faktor, salah satunya ialah kualitas pelayanan yang diberikan oleh PT TIKI JNE Cabang Pontianak. Walaupun demikian, kepuasan pelanggan PT TIKI JNE Cabang Pontianak juga akan dipengaruhi oleh kinerja dari PT TIKI JNE Cabang lain.

Hal ini disebabkan oleh sistem pengantaran kiriman pelanggan tidak hanya ditangani oleh satu kantor atau satu cabang saja, tetapi oleh cabang-cabang lain yang terlibat dalam pengantaran kiriman tersebut. Kualitas pelayanan ini merupakan salah satu aspek yang penting bagi PT TIKI JNE Cabang Pontianak dikarenakan PT TIKI JNE ini merupakan suatu perusahaan yang bergerak dalam bidang jasa pengiriman barang yang selalu dihadapkan dengan pelayanan secara langsung kepada konsumen pengguna jasanya.

\section{KAJIAN LITERATUR}

Dalam kajian pustaka ini akan diuraikan beberapa pengertian mengenai pelayanan jasa diantaranya; aspek tangibles (bukti fisik), reliability (keandalan), responsiveness (ketanggapan), assurance (jaminan dan kepastian), serta empathy (perhatian).

\section{Definisi Pelayanan}

Pelayanan merupakan suatu proses keseluruhan dari pembentukan citra perusahaan, baik melalui media berita, membentuk budaya perusahaan secara internal, maupun melakukan komunikasi tentang pandangan perusahaan kepada para pemimpin pemerintahan serta publik lainnya yang berkepentingan.

Adapun yang menjadi variabel dalam riset ini adalah kualitas pelayanan jasa dalam suatu studi mengenai SERQUAL (sevice quality) yang dikembangkan oleh Parasuraman, Zeithaml, Berry (2010) dalam buku Manajemen Pemasaran Jasa oleh 
Pelayanan Jasa aspek tangibles
Ririn Tri Ratnasari dan Mastuti H. Aksa disimpulkan terdapat 5 dimensi kualitas pelayanan jasa, yaitu :

a. Tangibles (bukti fisik), yaitu kemampuan suatu perusahaan dalam menunjukan eksistensinya pada pihak eksternal. Penampilan dan kemampuan sarana dan prasarana fisik perusahaan dan keadaan lingkungan sekitarnya adalah bukti nyata dari pelayanan yang diberikan oleh pemberi jasa, ini meliputi fasilitas fisik (gedung, gudang, fasilitas fisik, dan lainnya), teknologi (peralatan dan perlengkapan yang dipergunakan) serta penampilan pegawainya.

b. Reliability (keandalan), yaitu kemampuan perusahaan untuk memberikan pelayanan sesuai yang dijanjikan secara akurat dan terpercaya. Harus sesuai dengan harapan pelanggan, berarti kinerja yang tepat waktu, pelayanan tanpa kesalahan, sikap simpatik, dan dengan akurasi tinggi.

c. Responsiveness (ketanggapan), yaitu suatu kemauan untuk membantu dan memberikan pelayanan yang cepat (responsive) dan tepat kepada pelanggan, dengan penyampaian informasi yang jelas. Membiarkan pelanggan menunggu tanpa alasan yang jelas, menyebabkan persepsi yang negatif dalam kualitas jasa.

d. Assurance (jaminan dan kepastian), yaitu pengetahuan, kesopan-santunan, dan kemampuan para pegawai perusahaan untuk menumbuhkan rasa percaya pelanggan kepada perusahaan. Terdiri atas komponen: komunikasi (communication), kredibilitas (credibility), keamanan (security), kompetensi (competence), dan sopan santun (courtesy).

e. Empathy (perhatian), yaitu memberikan perhatian, tulus, dan bersifat individual atau pribadi kepada pelanggan dengan berupaya memahami keinginan pelanggan, dimana suatu perusahaan diharapkan memiliki suatu pengertian dan pengetahuan tentang pelanggan, memahami kebutuhan pelanggan secara spesifik, serta mmiliki waktu pengoperasian yang nyaman bagi pelanggan.

Para pelaku usaha jasa yang ada di Indonesia berlomba-lomba memberikan pelayanan terbaik mereka dengan berbagai strategi, salah satunya ialah strategi Marketing Mix (bauran pemasaran) yang akan menghasilkan kombinasi terbaik dari elemen $7 \mathrm{P}$ yang menjadi komponen marketing mix. 
Adapun menurut Buchari Alma, (2011:202-206) dalam Kewirausahaan Elemen $7 \mathrm{P}$ ini terdiri atas $4 \mathrm{P}$ tradisional dan $3 \mathrm{P}$ lagi sebagai tambahan untuk pemasaran jasa. Empat P tradisional berlaku untuk pemasaran barang, rinciannya adalah sebagai berikut:

$$
\mathrm{P} 1=\text { Product }
$$

Produk adalah merupakan titik sentral dari kegiatan marketing. Semua kegiatan marketing lainnya digunakan untuk menunjang pemasaran produk. Satu hal yang perlu diingat ialah bagaimana pun hebatnya usaha promosi distribusi dan harga yang baik tidak diikuti oelh produk yang bermutu dan disenangi konsumen maka kegiatan marketing mix ini tidak akan berhasil. Oleh sebab itu perlu diteliti produk apa yang anda pasarkan bagaimana selera konsumen maka kini perlu mendapat perhatian yang serius.

$$
\mathrm{P} 2 \text { = Price }
$$

Masalah kebijakan harga turut menentukan keberhasilan pemasaran produk. Kebijaksanaan harga dapat dilakukan pada setiap level lembaga yaitu kebijaksanaan harga oleh produsen, grosir dan reatiler.

Harga di sini bukan berarti harga yang murah saja ataupun harga tinggi akan tetapi yang dimaksudkan adalah harga yang tepat. Bagaimana menentukan harga yang tepat sangat tergantung kepada berbagai faktor misalnya faktor harga pokok barang, kualitas barang, daya beli masyarakat, keadaan persaingan, konsumen yang dituju dan sebagainya.

$$
\text { P3 = Price }
$$

Sebelum produsen memasarkan produknya, maka sudah ada perencanaan tentang pola distribusinya. Di sini penting sekali perantara dan pemilihan saluran distribusinya. Perantara ini adalah sangat penting karena dalam segala hal mereka berhubungan dengan konsumen. Kita dapat bayangkan, betapa sulitnya pasaran produk jika tidak ada orang yang menjalankan, tidak ada toko, kios, supermarket dan sebagainya. Dalam sebuah ungkapan dikatakan: You can eliminate the middle men, but you cannot eliminate their functions. Artinya: Anda dapat meniadakan perantara, akan tetapi tidak bisa menghilangkan fungsinya. Perantara dapat menjadi agen pembelian yang baik bagi para konsumen, dan dapat pula menjadi penjual yang ahli bagi produsen. 
Pelayanan Jasa aspek tangibles

006
P4 = Promotion

Antara promosi dan produk, tidak dapat dipisahkan, ini dua sejoli yang saling berangkulan untuk suksesnya pemasaran. Di sini harus ada keseimbangan, produk baik sesuai dengan selera konsumen, dibarengi dengan teknik promosi yang tepat akan sangat membantu suksesnya usaha marketing.

P5 = People

Adalah unsur orang / manusia yang melayani terutama dalam perusahaan yang menjual jasa. Termasuk kedalam P5 ini unsur pimpinan, yang mengambil keputusan dan unsur karyawan yang melayani konsumen. Karyawan ini perlu diberi pengarahan dan pelatihan agar dapat melayani konsumen sebaik-baiknya.

P6 = Physical Evidence

Artinya bukti fisik yang dimiliki oleh perusahaan jasa. Misalnya untuk penjualan jasa transportasi, konsumen akan memperhatikan kondisi mobil yang digunkan, untuk jasa hotel konsumen akan melihat tampilan hote, kamar dan berbagai fasilitas yang terdapat didalamnya.

P7 = Process

Yaitu bagaimana proses dilakukan sampai jasa yang diminta oleh konsumen diterima secara memuaskan. Apakah cukup puas menerima jasa, cepat layanannya, bersih, rapih, akurat, tepat waktu dan sebagainya.

Ketujuh P ini perlu kombinasi yang sesuai dengan keadaan komoditi yang diusahakan. Kombinasi mana yang akan digunakan sangat tergantung pada keahlian marketing dengan mempertimbangkan komoditi, pimpinan serta pengalaman masa lalu.

Definisi Jasa

Menurut Muhtosin Arief, (2005 : 13) menyatakan bahwa "Jasa merupakan semua aktivitas ekonomi yang hasilnya tidak berupa produk dalam bentuk fisik atau konstruksi, yang biasanya dikonsumsi pada saat yang sama dengan waktu yang dihasilkan dan memberi nilai tambah , seperti kenyamanan, hiburan, kesenangan atau kesehatan atau pemecahan yang dihadapi konsumen”.

Menurut Fandy Tjiptono, (2008 : 1) pengertian dari jasa adalah ”service umumnya mencerminkan produk tak berwujud fisik (intangible) atau sektor industri 
spesifik, seperti pendidikan, kesehatan, telekomunikasi, transporasi, asuransi, perbankan, perhotelan, konstruksi, perdagangan rekreasi dan seterusnya”.

Menurut Leonard L.Berry - H. Buchari Alma (2003: 5), ada 3 karakteristik jasa, Pelayanan Jasa aspek tangibles yaitu:

1. More intangible than tangible: Jasa merupakan perbuatan, penampilan atau sebuah usaha.

2. Simultananeous production and consumption: Jasa diproduksi dan dikonsumsi dalam jangka waktu yang sama. Dikatakan produksi dan konsumsi berjalan serempak artinya si penghasil jasa, sering hadir secara fisik pada waktu konsumsi berlangsung.

3. Less standarized and uniform: Jasa kurang memiliki standarisasi atau keseragaman. Pada waktu seseorang membeli jasa, sering kali bercampur dengan membeli barang-barang misalnya pada saat membeli mobil, selalu terkesan layanan jasa, keramah- tamahan penjual, layanan mobil purna jual. Seseorang makan di restoran sudah pasti diikuti dengan layanan jasa. Demikianlah selalu kita alami membeli tiket pesawat, kereta api, jasa kesehatan, asuransi, perbankan dan sebagainya, banyak layanan jasa yang berbeda intensitasnya.

Ada pun pendapat lain mengenai produk jasa memiliki karakteristik yang berbeda dengan barang (produk fisik). Menurut Griffin dalam buku Muhtosim Arief (2005:39) menyebutkan karakteristik jasa sebagai berikut:

a. Intangibility (tidak berwujud): Jasa tidak dapat dilihat, dirasa, diraba, didengar, atau dicium sebelum jasa itu dibeli. Nilai penting dari hal itu adalah nilai tidak berwujud yang dialami konsumen dalam bentuk kenikmatan, kepuasan, atau rasa aman.

b. Unstorability: Jasa tidak mengenal persediaan atau penyimpanan dari produk yang telah dihasilkan. Karakteristik ini disebut juga tidak dapat dipisahkan mengingat pada umumnya jasa dihasilkan dan dikonsumsi secara bersamaan.

c. Customization: Jasa juga sering kali didesain khusus untuk kebutuhan pelanggan, sebagaimana pada jasa asuransi dan kesehatan. 
Pelayanan Jasa aspek tangibles

008
Jasa juga dapat dapat diklasifikasikan berdasarkan skala tangible dominant to intangible- dominant. Tawaran jasa dapat berupa bagian kecil atau bagian utama dari tawaran total.

Dari beberapa definisi diatas maka dapat ditarik kesimpulan bahwa jasa pada dasarnya merupakan sesuatu yang tidak berwujud, yang dapat memenuhi kebutuhan dan keinginan konsumen. Dalam memproduksi suatu jasa dapat menggunakan bantuan suatu produk fisik tetapi bisa juga tidak. Di samping itu juga jasa tidak mengakibatkan peralihan hak suatu barang secara fisik atau nyata, jadi jika seseorang pemberi jasa memberikan jasanya pada orang lain maka tidak ada perpindahan hak milik secara fisik.

\section{Gambar 1}

\section{Kerangka Pemikiran Penelitian}

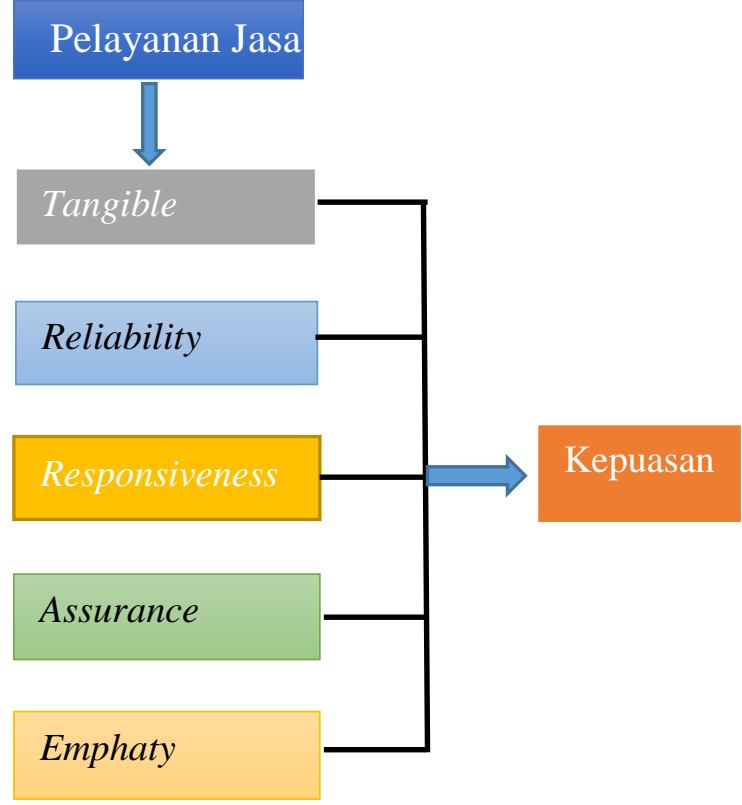

Sumber : Parasuraman, Zeithaml Berry, 2010

\section{Gambar 2}

Logo JNE 


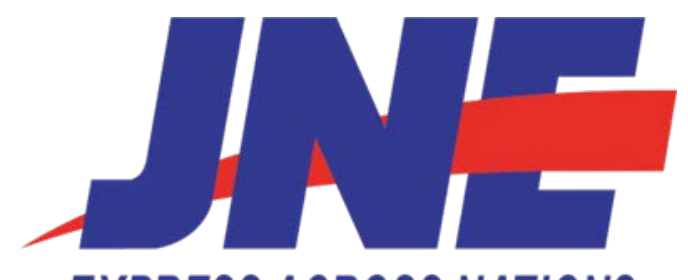

Pelayanan

Jasa aspek

tangibles

\section{EXPRESS ACROSS NATIONS}

Sumber : PT. Jalur Nugraha Ekakurir (JNE) Cabang Pontianak, 2018

Dengan satu garis melengkung yang mempunyai banyak arti serta dari nama perusahaan tersebut mencerminkan suatu efektifitas, lefisiensi, dan fleksibilitas serta dapat sejalan dengan misi perusahaan. Dengan berbekal motto perusahaan "EXPRESS ACROSS NATION" dapat lebih memperkuat tampilan logo sebagai suatu perusahaan jasa kurir. Keseimbangan dan kejujuran merupakan unsur terpenting dalam menjalankan sebuah usaha dengan tujuan dapat menata dengan baik menghasilkan output yang maksimal untuk menumbuhkan kepercayaan masyarakat yang merupakan unsur terpenting dalam sebuah perusahaan jasa kurir.

\section{METODE PENELITIAN}

\subsection{Metode Penelitian}

Menurut Sugiyono, (2004:1) dalam bukunya Metode Penelitian Bisnis metode penelitian pada dasarnya merupakan "cara ilmiah untuk mendapatkan data dengan tujuan dan kegunaan tertentu”.

Dari pendapat ahli diatas dapat disimpulkan bahwa metode penelitian yang diteliti sesuai dengan apa adanya secara ilmiah dengan tujuan menggambarkan untuk mendapatkan data dan kegunaan tertentu secara sistematis dan karakteristik objek yang diteliti secara tepat.

Adapun metode yang digunakan penulis adalah metode deskriptif yang bertujuan untuk mengumpulkan dan menganalisis informasi aktual secara rinci yang memutuskan gejala yang ada dan mengidentifikasikan masalah dalam penerapan pelayanan oleh karyawan-karyawati kepada konsumen pengguna jasa.

\subsection{Bentuk Penelitian}

Bentuk penelitian ini adalah bentuk penelitian Survey yaitu suatu teknik pengumpulan data informasi dilakukan dengan cara menyusun daftar pertanyaan 
yang diajukan kepada responden, mendatangi responden guna menanyakan informasi yang diminta serta dicatat dalam daftar kuesioner yang telah disiapkan. Jenis penelitian survey ini termasuk kedalam jenis penelitian deskriptif dan penelitian observasi. Hasil dari survey terhadap sampel tersebut kemudian digeneralisasikan atau diberlakukan kepada populasi, kemudian ditarik sebuah kesimpulan.

Menurut Kerlinger (1973) dalam buku Sugiyono, (2005:7) Metode Penelitian Bisnis mengemukakan bahwa "penelitian survey adalah penelitian yang dilakukan pada populasi besar maupun kecil, tetapi data yang dipelajari adalah data dari sampel yang diambil dari populasi tersebut, sehingga ditemukan kejadian-kejadian relatif, distribusi dan hubungan-hubungan antar variabel sosiologis maupun psikologis”.

\subsection{Populasi}

Populasi merupakan wilayah generalisasi yang terdiri dari objek atau subjek yang memiliki kuantitas dan karakteristik tertentu yang ditetapkan oleh peneliti untuk dipelajari dan kemudian ditarik kesimpulannya.

Menurut Sugiyono, (2014:80) "populasi adalah wilayah generalisasi yang terdiri atas: objek/subjek yang mempunyai kualitas dan karakteristik tertentu yang ditetapkan oleh peneliti untuk dipelajari dan kemudian ditarik kesimpulannya”.

\subsection{Teknik dan Alat Pengumpulan Data}

Dalam suatu penelitian selain diperlukan metode dan bentuk penelitian yang tepat, diperlukan juga teknik dan alat pengumpulan data yang tepat pula. Ketepatan dan kecermatan peneliti memilih teknik dan alat pengumpulan data yang tepat sangat berpengaruh terhadap objektivitas hasil penelitian.

Dengan kata lain teknik dan alat pengumpulan data yang tepat akan memungkinkan tercapainya pemecahan masalah secara efektif dan efisien pada gilirannya akan diperoleh rumusan generalisasi penelitain yang objektif.

\subsubsection{Wawancara}

Menurut Esterberg (2002) dalam buku Sugiyono, (2014:231), Metode Penelitian Kuantitatif, Kualitatif dan R\&D "wawancara adalah merupakan pertemuan dua orang untuk bertukar informasi dan ide melalui tanya jawab, sehingga dapat dikonstruksikan makna dalam suatu topik tertentu”. 
Teknik wawancara dalam penelitian ini yaitu mengumpulkan data dengan melakukan wawancara dengan pimpinan cabang PT Tiki Jalur Nugraha Ekakurir (JNE) Jl. H.O.S. Cokroaminoto No. 100 Pontianak. Dalam penelitian ini menggunakan teknik wawancara langsung.

\subsubsection{Studi Kepustakaan}

Studi kepustakaan adalah langkah yang diambil penulis dengan cara mempelajari atau membaca buku-buku atau literatur-literatur yang berkaitan dengan masalah yang akan dibahas oleh peneliti.

\subsubsection{Kuesioner}

Menurut Sugiyono, (2014:142) dalam bukunya Metode Penelitian Kuantitatif, Kualitatif, dan R\&D mengemukakan bahwa "kuesioner merupakan teknik pengumpulan data yang dilakukan dengan cara memberi seperangkat pertanyaan atau pernyataan tertulis kepada responden untuk dijawabnya.

Berdasarkan pengertian di atas dapat disimpulkan bahwa Kuesioner adalah daftar pertanyaan yang diberikan langsung kepada responden yang merupakan konsumen yang menjadi sampel penelitian pada PT Tiki Jalur Nugraha Ekakurir (JNE) di Jl. H.O.S. Cokroaminoto No. 100 Cabang Pontianak untuk menggali data sesuai dengan permasalahan penelitian.

\section{Teknik Analisis Data}

Teknik analisis data yang digunakan peneliti dalam penelitian ini adalah teknik analisis data kualitatif. Penganalisisan secara kualitatif ini dilakukan terhadap penelitian untuk argumentasi. Hal ini dilakukan berdasarkan data-data yang telah diperoleh melalui hasil observasi kemudian dari masing-masing jawaban pertanyaan ditarik kesimpulan.

\section{HASIL PENELITIAN DAN PEMBAHASAN}

4.1. Hasil observasi

Berdasarkan hasil observasi yang telah peneliti lakukan dengan Bapak Dwi Kepala Pimpinan Cabang PT Tiki Jalur Nugraha Ekakurir (JNE) Jl. H.O.S. Cokroaminoto No. 100 Pontianak pada tanggal 01 Maret 2018, mengenai kebijakan
Pelayanan Jasa aspek tangibles 
Pelayanan Jasa aspek tangibles

012

pimpinan dalam upaya meningkatkan jumlah konsumen pengguna jasa pada PT JNE.

Dalam hal ini pimpinan cabang PT JNE Pontianak mengambil berbagai kebijakan dalam meningkatkan jumlah konsumen antara lain :

4.1.1. Kualitas Layanan (Keandalan)

Kualitas layanan ini merupakan aspek yang sangat penting yaitu melayani dengan profesional kepada setiap masalah yang dari keluhan pelanggan pengguna jasa pengiriman barang PT Tiki Jalur Nugraha Ekakurir (JNE) Jl. H.O.S. Cokroaminoto No. 100 Cabang Pontianak.

\subsubsection{Daya Tanggap}

Daya tanggap ini adalah kebijakan yang dilakukan oleh PT Tiki Jalur Nugraha Ekakurir (JNE) Jl. H.O.S. Cokroaminoto No. 100 Cabang Pontianak dengan selalu menanggapi permasalah dan pertanyana yang diberikan oleh pelanggan untuk segera diatasi dan diberikan solusi yang tepat dengan kualitas layanan yang ramah dan sopan.

\subsubsection{Perhatian (empathy)}

Perhatian yang tinggi kepada pelanggan akan membuat pelanggan menjadi lebih merasa diperhatikan dan merasa lebih sangat diutamakan sehingga emosional pelanggan dapat terjga dan selalu beranggapan baik terhadap pelayanan yang diberikan oleh karyawan-karyawati PT Tiki Jalur Nugraha Ekakurir (JNE) Jl. H.O.S. Cokroaminoto No. 100 Cabang Pontianak.

\section{KESIMPULAN}

Berdasarkan pembahasan yang telah dibahas, maka dapat ditarik beberapa kesimpulan sesuai dengan kerangka pemikiran antara lain :

Persepsi konsumen pengguna jasa PT. Tiki Jalur Nugraha Ekakurir (JNE) cabang Jl. H.O.S. Cokroaminoto No. 100 Pontianak terhadap penerapan pelayanan melalui 5 dimensi SERQUAL (service quality).

\subsection{Tangibles (bukti langsung)}


Sebagian besar konsumen menyatakan bahwa lokasi PTTiki Jalur Nugraha Ekakurir (JNE) Jl. H.O.S. Cokroaminoto No. 100 Cabang Pontianak mudah untuk dijangkau, kebersihan dan kenyamanan terjaga

dalam ruangan kantor, area parkir yang cukup luas, serta karyawankaryawati berpenampilan rapi.

\subsection{Reliability (keandalan)}

Sebagian besar konsumen menyatakan bahwa karyawan-karyawati melayani dengan profesional, peusahaan juga cukup dapat diandalkan, kemampuan bersaing dengan perusahaan lainnya yang cukup mampu untuk bersaing, kesabaran karyawan dalam mengatasi keluhan, serta ketelitian yang ditunjukan oleh karyawan-karyawati.

5.3. Responsiveness (ketanggapan)

Sebagian besar konsumen menyatakan bahwa pelayanan yang diberikan karyawan-karyawai cepat dan tepat, informasi yang diberikan jelas serta kesopanan yang diberikan karyawan cukup sopan dalam pelayanan.

5.4. Assurance (jaminan dan kepastian)

Sebagian besar konsumen menyatakan bahwa pengetahuan yang dimiliki karyawan dalam menjawab pertanyaan pelanggan adalah baik, keamanan lingkungan kantor juga baik menurut responden serta perusahaan cukup berpeluang dalam persaingan dengan perusahaan lain sejenisnya.

5.5. Empathy (perhatian)

Sebagian konsumen menyatakan bahwa karyawan pengertian terhadap apa yang pelanggan butuhkan, karyawan juga mengutamakan / memprioritaskan keluhan pelanggan serta pengoperasian layanan yang nyaman bagi pelanggan.

\section{REKOMENDASI}

Pada akhir tulisan ini peneliti memberikan beberapa saran diantaranya :

1. Diharapkan pada PT. Tiki Jalur Nugraha Ekakurir (JNE) Jl. H.O.S. Cokroaminoto No. 100 Cabang Pontianak harus selalu memperhatikan dan 
Pelayanan Jasa aspek tangibles meningkatkan kualitas pelayanan kepada pelanggan pengguna jasanya dengan memberikan berbagai macam fasilitas yang nyaman, aman, serta layanan yang ramah kepada setiap pelanggan yang datang di kantor PT. Tiki Jalur Nugraha Ekakurir (JNE) Jl. H.O.S. Cokroaminoto No. 100 Cabang Pontianak.

2. Diharapkan PT. Tiki Jalur Nugraha Ekakurir (JNE) Jl. H.O.S. Cokroaminoto No. 100 Cabang Pontianak untuk selalu memberikan solusi dan jalan keluar kepada setiap pelanggan yang datang untuk mengkomplain masalah paket kiriman barangnya atau masalah lainnya yang berkaitan agar pelanggan dapat lebih mempercayai dan setia pada perusahaan jasa pengiriman barang PT. Tiki Jalur Nugraha Ekakurir (JNE) Jl. H.O.S. Cokroaminoto No. 100 Cabang Pontianak.

\section{DAFTAR PUSTAKA}

Aksa, H, Mastuti. 1998. Manajemen Pemasaran Jasa. Bogor : Ghalia Indonesia.

Alma, Buchari, H. 2011. Kewiraushaan Untuk Mahasiswa dan Umum. Bandung : Alfabeta.

Arief, Muhtosim. 2004. Statejik Pemasaran Jasa Pendidikan. Malang : Banyumedia Publishing.

‘2005. Pemasaran Jasa \& Kualitas Pelayanan. Malang : Banyumedia Publishing.

Kotler, Philip. 2002. Marketing Management International Edition. New Jersey : Phipe Prentice Hall.

Ratnasari, Tri, Ririn. 1998. Manajemen Pemasaran Jasa. Bogor : Ghalia Indonesia.

Sugiyono. 2002. Metode Penelitian Binis. Bandung : Alfabeta

'2004. Metode Penelitian Bisnis. Bandung : Alfabeta

'2005. Metode Penelitian Bisnis. Bandung : Alfabeta

'2014. Metode Penelitian Kuantitatif, Kualitatif dan R\&D. Bandung : Alfabeta.

Tjiptono, Fandi. 2008. Prinsip-Prinsip Total Quality Service. Yogyakarta : Ando Offset. 